\title{
Federalism vs. Federalismo: not all the roads lead to Rome ${ }^{1}$
}

\author{
Federalism x. Federalismo: nem todos os caminhos levam a Roma
}

\author{
Fernanda Duarte ${ }^{2}$ \\ Rafael Mario Iorio Filho ${ }^{3}$
}

\begin{abstract}
:
This paper is part of our research project that has been going on for a couple of years in our research group called "Center for Legal Studies, Citizenship, Procedure and Discourse", located at Estácio de Sá University, Rio de Janeiro, Brazil. In order to illuminate the idea that legal systems cannot be translated/verted straightforwardly as if they were a mere lexicon translation challenge, we apply the semiolinguistic methodology of discourse analysis and the method of comparison by difference (this latter borrowed from Antropology) to provide a description for native and/or theoretical categories of the Brazilian legal culture in contrast with American legal culture. We agree that there is much more about it that relates to meaning and understanding surpassing the linguistic problem. From the theoretical point of view our observations may be arranged in three sets of ideas: a) the understanding of Law as a set of local discourses and practices; b) the utility of the theoretical category "legal sensibilities" (GEERTZ ,1983); c) the recognition that culture interferes in socialization and social efficacy of Law when people translate legal categories. It is broadly said in Brazil that literal translations between legal concepts and categories of different legal systems are not only possible and but also feasible. For instance "judicial review" (controle de constitucionalidade in Portuguese) would be the same in American and Brazilian law, as if the words would only need a proper and accurate translation exercise to convey their proper meaning. However to show that this correspondence is tricky and dangerous we have been selecting different categories and putting them into description and analysis in the Brazilian and American legal cultures. Previously we have dealt with two other categories: equal protection vs. igualdade juridica and due process of law vs. devido processo legal. This turn we have picked the category of federalism (federalismo in Portuguese). We believe this approach can work as a vaccine against uncritical transplantations of legal categories that ultimately become out of place with low capacity to interfere with reality and to shape behaviors that involve the enforcement of law.
\end{abstract}

\footnotetext{
${ }^{1}$ This paper was presented at the Annual Meeting on Law and Society 2017Mexico City. On this opportunity we had the chance to engage on a debate with Professor Seth Davis from Irvine School of Law,University of California to whom we would like to express our gratitude. Prof. Davis has helped us understand the limits of our discussion pointing to another horizon if we consider the American federalism through administrative law.

${ }^{2}$ Estácio de Sá University, INCT-InEAC/UFF, PhD, Law Professor, CRN1/LSA.
}

${ }^{3}$ Estácio de Sá University, INCT-InEAC/UFF, PhD, Law Professor, CRN1/LSA.

Revista Juris Poiesis - Rio de Janeiro. Vol.21-n²5, 2018, pg.147- 165. ISSN 2448-0517

Rio de Janeiro, 29 de abril de 2018. 
Keywords: constitutional theory; legal culture; comparative perspective; federalism in the US; federalism in Brazil.

\section{RESUMO:}

Este trabalho faz parte de nosso projeto de pesquisa que ocorre há alguns anos em nosso grupo de pesquisa denominado "Núcleo de Estudos sobre Direito, Cidadania, Procedimento e Discurso", localizado na Universidade Estácio de Sá, Rio de Janeiro, Brasil. Para iluminar a ideia de que os sistemas jurídicos não podem ser traduzidos diretamente como se fossem um mero desafio de tradução/versão do léxico, aplicamos a metodologia semiolinguística da análise do discurso e o método de comparação por diferença (este último emprestado da Antropologia) para fornecer descrição para categorias nativas e/ou teóricas da cultura jurídica brasileira em contraste com a cultura legal americana. Entendemos que há muito mais sobre o significado e a compreensão que ultrapassa o problema linguístico. Do ponto de vista teórico, nossas observações podem ser organizadas em três conjuntos de ideias: a) a compreensão do Direito como um conjunto de discursos e práticas locais; b) a utilidade da categoria teórica "sensibilidades jurídicas" (GEERTZ, 1983); c) o reconhecimento de que a cultura interfere na socialização e na eficácia social da lei quando as pessoas traduzem as categorias legais. É amplamente dito no Brasil que traduções literais entre conceitos jurídicos e categorias de diferentes sistemas jurídicos não são apenas possíveis, mas também viáveis. Por exemplo, "judicial review" nos Estados Unidos seria "controle judicial de constitucionalidade" no Brasil, como se as palavras só precisassem de um exercício de tradução/versão correto e preciso para transmitir seu significado apropriado. No entanto, para mostrar que essa correspondência é complicada e perigosa, selecionamos diferentes categorias e as colocamos em descrição, em breve análise nas culturas jurídicas brasileira e americana. Em outra oportunidade lidamos com duas outras categorias: equal protection/igualdade jurídica e due process of law/devido processo legal. Nesta oportunidade, escolhemos a categoria federalismo/federalismo. Acreditamos que essa abordagem pode funcionar como uma vacina contra transplantes de categorias normativas pouco reflexivos e que acabam se tornando inadequados, com baixa capacidade de interferir na realidade e moldar comportamentos que envolvem a aplicação da lei.

Palavras-chave: teoria constitucional; cultura jurídica; perspectiva comparada; federalismo nos EUA; federalismo no Brasil. 
This paper is part of our research project that has been going on for a couple of years in our research group called "NEDCPD: Center for Legal Studies, Citizenship, Procedure and Discourse", located at Estácio de Sá University, in Rio de Janeiro, Brazil.

In order to illuminate the idea that legal systems cannot be translated/verted straightforwardly as if they were a mere lexicon translation challenge, we apply the semiolinguistic methodology of discourse analysis and the method of comparison by difference (this latter borrowed from Antropology) to provide a description for native and/or theoretical categories of Brazilian legal culture in contrast with American legal culture. We agree that there is much more about it that relates to meaning and understanding surpassing the linguistic problem. From the theoretical point of view our observations may be arranged in three sets of ideas: a) the understanding of Law as a set of local discourses and practices; $b$ ) the utility of the theoretical category "legal sensibilities" (GEERTZ ,1983); c) the recognition that culture interferes in socialization and social efficacy of Law when people translate legal categories. It is broadly said in Brazil that literal translations between legal concepts and categories of different legal systems are not only possible and but also feasible. For instance "judicial review" (controle de constitucionalidade in Portuguese) would be the same in American and Brazilian law, as if the words would only need a proper and accurate translation exercise to convey their proper meaning. However to show that this correspondence is tricky and dangerous we have been selecting different categories and putting them into description and analysis in the Brazilian and American legal cultures. Previously we have dealt with two other categories: equal protection vs.igualdade juridica and due process of law vs. devido processo legal. This turn we have picked the category of federalism (federalism in Portuguese). We believe this approach can work as a vaccine against uncritical transplantations of legal categories that ultimately become out of place with low capacity to interfere with reality and to shape behaviors that involve the effectiveness of law.

So as it was mentioned before, this presentation is the result of another stage of a work that we have developed, over the years, especially linked to the CRN1, which precisely seeks to discuss the translation of categories that integrate the legal culture of Brazil and the United States, assuming that construction of the senses is distinct from the literal translation of the terms and must be perceived and analyzed taking into account the local legal culture and its legal sensibilities (GEERTZ: 1998 and GEERTZ: 2008). 
On this paper we are also using the method of comparison by difference or contrast, typical of the interpretive Anthropology and we intend to provide a first description of the relation between Federalism and Federalismo (in Portuguese), so that we can perceive the meanings of the States' design exclusively on constitutional grounds ${ }^{4}$ and how it affects the legal order, defining a sphere of autonomy, intervention and protection of the rights by the state in society.

Federalism ${ }^{5}$ is in a relevant subject both to the researcher of Constitutional Law and to one who is dedicated to the study of Political Science. Constitutional Law, due to the material content of the Constitution, is devoted to the study of the organization and functioning of the government, promoting a study of its anatomy.

Federalism, or the federation, as a mode or method of government is linked to this anatomy, since it presents the division of the territory of the government into different entities (states), each exercising its constitutionally established portion of competence (CAMARGOS and ANJOS, 2009: 81). Thus in the federalist state we have the coexistence of different legal orders, in the same geographic space which implies that in a federalist government, the power is divided between the national government and other governmental units.

For the Political Science, which main interest is political power, federalism deals with the division of political power through federation. In the view of Arend LIJPHART (2003: 213):

In this chapter, I address the first variable of the unitary federal dimension (divided power): federalism and decentralization versus unitary and centralized government. It is appropriate to give this first place of honor to federalism because it can be considered the most typical and drastic method of the division of power: it divides power between entire levels of government. In fact, as the term of political science, the division of power is usually used as a synonym for federalism.

In this way, understanding federalism as a phenomenon of division of power is the same as analyzing it as the division of the main object of study of Political Science.

\footnotetext{
${ }^{4}$ It is important to mention that much of the details and debate about federalism in the U.S. nowadays get worked out through administrative agencies. Thus, constitutional law alone does not provide the full picture of American federalism (see METZGER: 2018; BULMAN-POZEN: 2018; GREVE: 2018).So our comparative work is to be taken within the borders of constitutional law. Actually, this could pointed out as another difference. While in Brazilian law federalism is a constitutional issue in the US law it is a matter of administrative law.

5 "Federalism is a political organization in which the activities of government are divided between regional governments and a central government in such a way that each kind of government has some activities on which it makes final decisions." (RICKER, 2008:12). 


\title{
Federalism in the U.S.
}

Federalism as a mode of government appears as a construction of the eighteenth century, more precisely linked to the American constitutionalist movement, which succeeded the American independence revolution.

To address the origins of US federalism, it is necessary to discuss one of its most important assumptions: the US Constitution. American constitutionalism legacy was initially presented to the world through the Philadelphia Convention, the first Constitution written in 1787. And a form of government that until then was unknown to world, was ingeniously proposed: the federalist mode which goes back to the period of appearance of the American state itself. The US Constitution is the basis for the validity of federalism ${ }^{6}$.

As CAMARGOS and ANJOS (2009: 83), two Brazilian political scientists who are dedicated to the study of American federalism, tell us:

\begin{abstract}
It was from the union of the thirteen former English colonies, formed by individuals from England, who went to the new world for religious, political and economic reasons, that was created initially a Confederation in the moment immediately after the independence. Confederation, which has brought about adjustments and a closer rapprochement between the Confederate States, in order to bring about a Federation. In the Federation each of the thirteen former colonies, which were formerly constituted in Confederate States, had to give up the sovereignty of which they were endowed to constitute a power that was placed in a higher instance and that encompasses all of them, being therefore the sovereignty Attributed to this power, thus appearing the Federal State. (free version to English).
\end{abstract}

According to Alexander HAMILTON (2003: 71), author of "The Federalist," the reference work on this new form of government organization, the autonomy of its member states combined with a solid and indissoluble union between them is the hallmark of a federation, as confirmed by the text of the author transcribed below:

\begin{abstract}
A solid Union will have the greatest significance for the peace and freedom of the member states as a barrier against internal factions and insurrections. It is impossible to read the history of the small republics of Greece without a sense of horror and grief at the agitations to which they were continually subjected and the rapid succession of revolutions which left them in a state of constant oscillation between the extremes of tyranny and anarchy.
\end{abstract}

\footnotetext{
${ }^{6}$ In the U.S., there is also a school of thought that it is Congress - not the Constitution (i.e., courts interpreting the Constitution) or agencies - that primarily designs federalism. This school is summarized in GLUCK (2018). 
In the case of the federation of the United States of North America, it was noted that there were constant concerns about the foreign policy, trade and security issues of the federal states $^{7}$ gathered around the Union. However, the main concern was (and which has led to the War of Secession, in which it was established that the member states of the Federation could not leave it, that is to say, there was no right of secession), and, later, in federal states they would have to face.

\section{Federalismo in Brazil}

Brazil was originally a Portuguese colony since 1500 and became an independent nation in 1822 where then monarchy was the political system adopted which has called itself as an empire. The Brazilian imperial constitution established a unitary government, presenting as characteristics the strong political and administrative centralization. It is true that this centralization resulting from the unitary state form greatly aided in the construction of national unity, thus preventing the country from disintegrating because of the numerous revolts that occurred within the provinces (CHACON, 1987).

In Brazil, the transition from the monarchy to the republic and from the unitary state to the federal state was not a slow but relatively brief process. The fact is that this great transformation in national political life was the work of a few high-ranking intellectuals and military personnel, and there was no popular participation in the process of this process (CAMARGOS and ANJOS, 2009).

On this subject, José Murilo de Carvalho (1991: 68) says: "These observations are not, however, far from the phrase of Aristides Lobo, according to which the people would have witnessed Proclamation of the Republic, without understanding what was happening ".

It is necessary to show that the degree of alienation of the people with regard to the national political moment was not very different from the lack of participation of the political leaderships existing in the provinces with regard to the adoption of federalism as a form of governmet. The republic and federalism were a movement of intellectuals and soldiers who resided in the court and in the province of São Paulo. The other provinces did not take a

\footnotetext{
${ }^{7}$ The Confederation would be another form of organization, in which sovereign states unite by treaty and by reason of a common objective, but without loss of sovereignty. There is the possibility of withdrawal from the Confederation, that is, the right of secession is assured. It is recalled that the American Civil War, from 1861 to 1865, was related to this theme. The Southern States saw themselves with the right to withdraw from the United States, hence the Confederate States. Defeated in the war by the Northern States (known as the Yankees), it became a US federation, barred from the right of secession.
} 
significant part in the historical event, and if it is true that the federative pact does not require a historical moment for its characterization, in Brazil it was expressed with the elaboration of the Republican Constitution of 1891 (CAMARGOS and ANJOS, 2009).

It is true that in the 1934 Constitution many of the administrative and legislative powers attributed to the states were previously transferred to the Union. However, in 1937, with the advent of the coup given by Getúlio Vargas, the granting of a new Constitution and the institution of the dictatorship of the New State until 1945, Brazil lived moments of great political centralization, when states did not even have the political weight presented in the years after the 1 st Republic.

Under the Constitution of 1946, the country experienced a new period of democratization and the states of the Federation began to act in the national political scene with greater ease, however, this Constitution adopted the same pattern of concentration of administrative and legislative powers in the role accorded to the Union (CAMARGOS and ANJOS, 2009). With the advent of the military coup of 1964, which established the dictatorship and culminated in the 1967 Constitution and Amendment No 1 of 1969, returning to a period of strong centralization and authoritarianism by the federal Union, where there is a true submission of the federal states to the Union.

With the re-democratization of the country and the convening of the National Constituent Assembly in 1986, whose work resulted in the 1988 Constitution, the country returned to the rule of law, a right that was elaborated and legitimately exercised. In spite of the political setbacks faced by the country in its republican history, the fact is that the territorial dimensions of Brazil, which are of great proportions, impose to a greater efficiency in the administration of the public thing the political and administrative decentralization.

The Political Charter of 1988 established in its art. 1. "The Federative Republic of Brazil, formed by the indissoluble union of States and Municipalities and the Federal District, constitutes a Democratic State of Law and has as its foundation: [...]"

It is to be noticed that there was a great innovation of the Constitution when establishing that Brazil is a federation constituted by states, municipalities and by the federal district, innovation that is given by raising the municipality to an autonomous entity of the federation. It is widely known that the federation consists only of states, which together with the union presents its dualistic aspect, hence the great innovation in the new structure presented by Brazilian federalism. 
The art. 18 of the 1988 Constitution of the Republic presents the municipality as an integral part of the administrative political organization of the Federative Republic of Brazil alongside the Union, the States and the Federal District, all of which are endowed with autonomy. Although, as far as the institutional design is concerned, the Municipalities do not present Judicial Power. This exists only at the federal and state levels.

The Brazilian federation acquires a certain peculiarity when presenting three spheres of government that would be the Union, the states and the municipalities, but authors like José Afonso da Silva question whether the municipality was, in fact, elevated to the category of federative entity (SILVA, 2007: 641)

And did the Municipalities even become federated units? The Constitution does not say so. On the contrary, there are eleven occurrences of the expressions 'federated unit and unit of the Federation' referring only to the States and the Federal District, never involving the Municipalities.

Thus, for these authors it is admitted that the Municipalities are part of the Federation, but they are not federated entities so calledproperly.

Being the Brazilian government a Federation, we will then have the existence of different levels of power - three in our case: federal, state and municipal - with their respective structures, which must live harmoniously as established by the federative principle and in light of the principle of Separation of powers. This harmony presupposes a balance between the different federal, state and municipal legal orders - as partial orders - that must be articulated with the total order of constitutional matrix. There is the challenge here of symmetries and autonomies that arise in everyday life and that often generate situations of federal conflicts that, when they are judicialized, end up in the Federal Supreme Court.

\section{Not all the roads lead to Rome: which means that not all federalist experiences are the same}

In this item we have picked out three differences between Brazilian federalism and US federalism that need more elaboration and discussion if we want them to be taken more seriously. And weacknowlegde that these differences are not exaustive so many others could be pointed out, so the debate is open. But as this is a work in progress we dare to share these ideas now. 


\section{Divergent path \#1}

As it was already mentioned before, the US federalist model emerged in 1787 with the ratification of the Constitution by the then sovereign states, with the purpose of joining forces, through a central government, to face external dangers, making them autonomous entities ${ }^{8}$.

In Brazil, it was with the proclamation of the Republic and through its Decree $n^{\circ} 1$ in 1889 that federalism was established, reproduced throughout our constitutional history from then on, and with the indelible marks of an exaggerated amount of competences attributed to the Union (which can be understood as a permanent idea of the empire) and the oscillation of the degree of centralization and decentralization of federative entities throughout time.

This is the first path that does not lead to Rome: the cultural historical context of both societies.

US federalism is the gathering of independent state forces, which have abdicated part of their sovereignty for the strengthening of all. We can consider this political design as federalism by aggregation. And as a legal consequence the Tenth Amendment gave the states all powers not delegated to the national government or denied to the states. In other words, under federalism, the states regulate whatever is left over, which reminds us of the idea of a centripetal force. And the struggle between the national and the states governments has never been set out throughout American history. This tension can be illustrated ${ }^{9}$ by the discussions involving the concepts of "devolution ${ }^{10}$ "; "new federalism ${ }^{11}$ "; "devolution revolution" "doctrine of implied powers ${ }^{13}$ "; etc...

\footnotetext{
${ }^{8 "}$ "One of the first objects of the establishment of all civil societies is their security against external dangers; and this is the essential and indisputable object of the American Union. Therefore, it is clear that the powers necessary for this purpose must be entrusted to the Federal Government."(HAMILTON; MADISON; JAY, 2003:252).

9 For picking up these examples we have chosen information available on sites that are directed to the general population because they have the goal to explain to the layman complex issues and in a way they likely manage to convey more the meaning than the theoretical debate.
}

10"Devolution is the transfer of certain powers from one entity to another. It's an effort to reduce federal government powers by transferring some responsibilities to the state governments. Through devolution, the states gain responsibility for matters that were previously handled at the federal level."'.'( http://study.com/academy/lesson/devolution-definition-examples.html)

${ }^{11}$ US "[...]moved toward new federalism in the 1970s and 1980s, mostly under the direction of Republican presidents Nixon and Reagan. New federalism allows the states to reclaim some power while recognizing the federal government as the highest governmental power. It's a response to the argument that the federal government grew too powerful during years of operation under other federalism theories. Under new federalism, 
While the Brazilian federalist experience resulted of the decentralization of a sovereign and unitary government. So it is said to be a federalism by disaggregation, as if a centrifugal force was pushed into the Empire fractioning its unity into other political entities. As a legal result, in Brazilian legal tradition the Union has all the powers that were not explicit given to the states.

The realization of this difference leads us to another path that also does not lead us to Rome: the North American model of division of powers reveals a dual federalism, the union deals with general matters and the states regulate their local interests. On the other hand, the Brazilian model with its constitutional common and competing competences, when establishing a close approximation between the entities and concentration of competences in the hands of the union, is classified as a cooperative federalis $\mathrm{m}^{14}$.

\section{Divergent path \#2}

government powers are still divided between the federal government and the states. However, the states assume responsibility for federal programs".( http://study.com/academy/lesson/devolution-definition-examples.html)

12"'President Reagan campaigned for the 1980 presidency promising to curb the size and influence of the federal government. By the mid 1990s, the term devolution revolution was used to describe this particular era of politics where federal programs were downsized and state responsibilities were increased. The devolution revolution especially applied to various social programs, though Social Security and Medicare remain largely untouched.Devolution increased in popularity because many politicians thought federal grants had been improperly used to impose the interests of the federal government on the individual states. Through devolution, the federal government instead provides large block grants, or blocks of money, to the states to be used for specific social programs". ( http://study.com/academy/lesson/devolution-definition-examples.html)

13“'Implied powers are powers that are not specifically given to the government by the U.S. Constitution, but that are implied because they are necessary to carry out the powers that are expressly listed in the Constitution. In other words, implied powers are the secondary powers that the government has because of the existence of the primary powers. The implied powers of Congress are also called the Elastic Clause and has been the source of much controversy over the years. This power can be found under Article I, Section 8, Clause 18 of the Constitution, marked as the "Necessary and Proper Clause." The idea behind the clause is that additions to the regulations may be deemed to be necessary and proper for the ongoing running of something in particular, such as interstate commerce. Since the definition of what is necessary or proper can vary greatly depending on who is asked, this has always been a point of contention". (https://www.justipedia.com/definition/13493/impliedpowers)

14 "In cooperative regimes, states draw their power from their position as federal servants, not separate sovereigns. [...] Their power looks more like that wield by a street level bureaucrat than that exercised by a separate and autonomous government. [...] In sum, states wield power in cooperative federal regimes, but the power they wield is that of the servant, not the sovereign; the insider, not the outsider." (HEATHER, 2012: 1557-1558). 
The second difference that leads to different paths stands out in our studies as the legal system, focused in the constitutional text and this topic is especially relevant to Brazil's legal system.

Unlike the US Constitution which is written in very few provisions and some amendments, the 1988 Brazilian Constitution ${ }^{15}$ is extremely long, comprehensive and extensive (with 250articles and 90 amendments approved up to June 2017) and there are many provisions that are dedicated to establish a legislative division of power between the Union and the states. Many techniques throughout Brazilian history have been adopted in order to define and redefine this division and Brazilian scholars have tried to provide a logical explanation to all of them, describing the different methods that are or can be used to allocate powers, such asthe horizontal and the vertical model. In Brazilian legal literature, the horizontal division of powers is a rigid determination of what each entity is competent, listing the competence of the Union and reserving competence to States and Municipalities. In this case, there should be no kind of subordination between the entities which perform their normative duty without mutual interference. The horizontal model happens when there is the possibility of different political bodies legislating on the same subject, adopting the predominance of the Union, which will legislate in the general norms (article 24, § $1^{\circ}, \mathrm{CF} 88$ ) while by virtue of the additional or complementary power the states legislate on matters relating to their local interests(article $24, \S 2^{\circ}, \mathrm{CF} 88$ ). The idea of complementing here means detailing and specifying and the semantic problem arises when one has to define what "local" implies.

In American literature, the concepts are slightly different:

The U.S. Constitution allocates sovereign power along two dimensions: a vertical plane that establishes a hierarchy and boundaries between federal and state authority, and a horizontal plane that attempts to coordinate fifty coequal states who must peaceably coexist. Both vertical and horizontal federalism are fundamental elements of American government" (ERBSEN, 2008)

At the present, the Brazilian constitutional provisions on this subject are articles 22, 23 and 24, but it is important to notice that the major subjects that are relevant to people's live (including here family life and development of economic activities for instance) are subordinated to the Union power.

\footnotetext{
${ }^{15}$ You can find here an English version of the 1988 Brazilian Constitution which was prepared by the Brazilian Congress (Federal Senate) and updated in 2013 :<http://www.stf.jus.br/repositorio/cms/portalStfInternacional/portalStfSobreCorte_en_us/anexo/Constitution_20 13.pdf>
} 
Let's consider what article 22, I says: "The Union has the exclusive power to legislate on: I - civil, commercial, criminal, procedural, electoral, agrarian, maritime, aeronautical, space and labour law".

Because of this constitutional determination, and reinforcing Brazil's affiliation to the civil law tradition, there are innumerous Codes and statues that regulate the Brazilian statutory system all over the nation and that are to be enforced on the national territory as a whole. So this means that there is only one Civil Code, one Civil Procedural Code, one Criminal Code, one Criminal Procedural Code, one Labour Statue, one Commercial Code, etc.... This peculiar design means that the Brazilian Congress sometimes legislate within a nationalwide range, in the name of the whole Brazilian nation, but other times it works within the federal level, considering just the Union boundaries. In this case the law applies to the federal level, but not within the state or the municipality territory. The first one is considered a "federal national bill". It is federal because it was provided by the Federal Congress, but it is national because it is valid throughout the country, for example, considering consumerist law which is regulated by the Consumer Code (Bill No 8.078, passed on September 11th.1990), the normative text establishing consumer's rights is exactly the same no matter where you are. The latter is considered a "federal federal bill": it is federal because it was voted by the Federal Congress, but is federal (again), because it is meant only for the Union as a federal entity. For instance, regarding federal employees, we have Bill No. 8112 passed on December 11th 1990 that regulates the rights and duties of the people that work for the Federal Executive Branch and therefore called public servants (servidores públicos).

For an American citizen it is perfectly regular and ordinary that felonies have different kinds of penalties within the whole lot of the American states. For instance, considering murder, one can debate over the violation of the human rights protection, but it is a fact that a person can be sentenced to death in 30 out of 50 US states. In Georgia, you can be sentenced to death by lethal injection, but in Utah a firing squad can be the selected method ${ }^{16}$. But for Brazilians this is constitutionally impossible. According to the Brazilian Criminal Code (art.121), murder is punished serving prison for the basic period in jail that varies from 6 to 20 years, according to the circumstances of the case.

$\begin{aligned} & \text { For more } \\ & \text { information, see DPIC-Death Penalty Information }\end{aligned}$ Center at
<https://deathpenaltyinfo.org/descriptions-execution-methods?scid=8\&amp;did=479>
Revista Juris Poiesis - Rio de Janeiro. Vol.21-n $n^{\circ} 25$, 2018, pg.147- 165. ISSN 2448-0517 Rio de Janeiro, 29 de abril de 2018. 
So in the normative dimension and we are not taking into consideration now the differences we can find in interpreting and applying the law to real case ${ }^{17}$, there is very little diversity and a lot of normative uniformity since what really matters is subjected to "federal national"statues that are to be applied through the whole Brazilian country, by federal or even state judges, as we will discuss latter in this presentation. So once you have grasped what is the meaning of law in the Civil Code, this understanding can be expanded to anywhere in Brazil, at least on an ideal level.

\section{Divergent path \#3}

Last but not least, we would like to talk about the Judicial Branch in both countries, calling attention to two aspects that can easily illustrate the idea of different paths: judicial body diversity and jurisdiction.

Regarding the judicial bodies, it seems to us that in the US there is a fairly clear sense amongst judges and the people in general that due to the federal system, the judicial bodies are as diverse as the number of the states that integrate the Federation and the only court that was created by the Founding Fathers is the US Supreme Court. This diversity implies that there might be courts ${ }^{18}$ where some judges can be elected, as it happens in most of the American states, while others are appointed, as it happens to federal judges. Their wages, retirement systems etc... can be different as well. So if one wants to study the judicial branch the first question that pops up is: are you talking about federal judges or which state court are you considering?

While in Brazil's system, the Judicial Bodies - either federal or state courts ${ }^{19}$ - are all described in the 1988 Constitution which has established standards to be observed when court building. There is a "national" flavor here which has set the path for uniformity, meaning that there are constitutional mandatory principles to be observed that transcend the federal/state

\footnotetext{
${ }^{17}$ This aspect is one of our areas of studies, as seen in IORIO FILHO \& DUARTE (2010).

${ }^{18} \mathrm{~A}$ very interesting description of the US Courts is provided by CORLEY et al. (2016).

${ }^{19}$ CF 88 art 92: "The following are the bodies of the Judicial Power: I - the Supreme Federal Court; I-A - the National Council of Justice; II - the Superior Court of Justice; III - the Federal Regional Courts and the Federal Judges; IV - the Labour Courts and Judges; V - the Electoral Courts and Judges; VI - the Military Courts and Judges; VII - the Courts and Judges of the states, of the Federal District and of the territories. Paragraph 1. The Supreme Federal Court, the National Council of Justice, and the Superior Courts have their seat in the Federal Capital. Paragraph 2. The Supreme Federal Court and the Superior Courts have their jurisdiction over the entire Brazilian territory."
} 
dimension, neighbouring an unitary political model. These principles are established in article 93 and define all the structure of the Brazilian Judiciary (federal and state bodies) such as: establishing admission into the career $^{20}$, promotion from level to level ${ }^{21}$, retirement rules, financial compensation related to the level of jurisdiction, the importance of judicial education, acts of removal, etc...

It is also defined by the Constitution that all judgments of the bodies of the Judicial Power shall be public, and all decisions shall be justified, under penalty of nullity, but the law may limit attendance, in given acts, to the interested parties and to their lawyers, or only to the latter, whenever preservation of the right to privacy of the party interested in confidentiality will not harm the right of the public interest to information.

Courts will operate continuously, without interruption, collective vacation being forbidden for first instance judges and courts of second instance, and there must be judges on duty at all times on days in which courts are closed.

Even the size and the composition of the courts are controlled by the Constitution meaning that the number of judges in each court is proportional to the effective judicial demand and to the respective population. Regarding the composition there is the "one-fifth rule" that establishes that one-fifth of the seats of the Federal Regional Courts, of the Courts of the States, and of the Federal District and the Territories shall be occupied by members of the Public Prosecution, with over ten years of office, and by lawyers of notable juridical learning and spotless reputation, with over ten years of effective professional activity, nominated in a list of six names by the entities representing the respective classes. And the Constitutional goes further: upon receiving the nominations, the court has to organize a list of

\footnotetext{
${ }^{20} \mathrm{CF}$, art.93: "I - admission into the career, with the initial post of substitute judge, by means of a civil service entrance examination of tests and presentation of academic and professional credentials, with the participation of the Brazilian Bar Association in all phases, at least three years of legal practice being required of holders of a B.A. in law, and obeying the order of classification for appointments; "

${ }^{21}$ “CF, art.93: II - promotion from level to level, based on seniority and merit, alternately, observing the following rules: a) the promotion of a judge who has appeared in a merit list for three consecutive times or for five alternate times is mandatory; b) merit promotion requires two years in office in the respective level and that the judge should appear in the top fifth part of the seniority list of such level, unless no one satisfying such requirements is willing to accept the vacant post; c) appraisal of merit according to performance and to the objective criteria of productivity and promptness in the exercise of the jurisdictional function and according to attendance and achievement in official or recognized improvement courses; d) in determining seniority, the court may only reject the judge with the longest service by the justified vote of two-thirds of its members, according to a specific procedure, full defense being ensured, the voting being repeated until the selection is concluded; e) promotion shall not be granted to a judge who unjustifiably withholds case records beyond the legal deadline, and he may not return them to the court archives without providing the necessary disposition thereof or decision thereon;"
} 
three names and will send it to the federal or state Executive Power, which will select one of the listed names for appointment, within the subsequent twenty days.

Judges guarantees are also described in the constitutional text (article 95), such as life tenure; irremovability, save for reason of public interest, under the proper procedure (article 93, VIII); and irreducibility of compensation. And judges are forbidden to:I.hold, even when on paid availability, another office or position, except for a teaching position; II.receive, on any account or for any reason, court costs or participation in a lawsuit; III. engage in political or party activities; IV - receive, on any account or for any reason, financial aid or contribution from individuals, and from public or private institutions, save for the exceptions set forth in law; V - practice law in the court or tribunal on which they served as judges, for a period of three years following their retirement or discharge.

On the other hand, it is also true that the US Constitution deals with the Judicial Branch in its article III, section $1^{22}$ but those provisions are strictly directed to the Supreme Court and the federal judiciary only, leaving room for state disposition through legislation. But in Brazil considering that these standards are constitutional rules designed for all courts,there is little room for legislative creativity which implies a very rigid and strict model that strengthens court's uniformity to the detriment of autonomy and diversity, reducing in a very significantly way the federalist aspect of the Brazilian Judicial Branch. This idea of a "National Judicial Branch" 23 as a result of the federal and state courts assembled together is so embedded in the judicial Brazilian culture that whenever a state court gets any kind of benefit from one state legislator (for instance reimbursement for housing expenses), federal judges and/or other state judges claim that they are entitled the same benefit because there is a symmetry principle (principio da simetria) inscribed in the Constitution that commands symmetrical treatment for Brazilian judges and the federalist argument is not strong enough to justify this difference. The unitary mindset prevails reinforcing a centralized mentality that

\footnotetext{
${ }^{22}$ US Constitution, art. III, section 1: "The judicial Power of the United States, shall be vested in one supreme Court, and in such inferior Courts as the Congress may from time to time ordain and establish. The Judges, both of the supreme and inferior Courts, shall hold their Offices during good Behaviour, and shall, at stated Times, receive for their Services, a Compensation, which shall not be diminished during their Continuance in Office".

${ }^{23}$ The reference of a National Brazilian Judicial Power can be easily found in the National Council of Justice documents, such as the National Goals for the Judicial Branch (seehttp://www.cnj.jus.br/noticias/66623-poderjudiciario-nacional-tera-que-cumprir-10-metas-ate-o-final-do-ano). This council (Conselho Nacional de Justiça - CNJ in Portuguese) was created by the Constitutional Amendment no. 45 (art. 103A) to oversee all the judicial branches in Brazil, basically controlling the administrative andfinancial operation of the Judicial Branch and the proper discharge of official duties by judges.
} 
is not friendly to federalist systems and does not recognize the different budget limits that the federal government and the state's governments are submitted to, for instance.

The second aspect in this presentation that remains to be discussed is related to federal and state jurisdiction which definitely stress that we are leading two different roads with different consequences for the legal dimension.

In the US legal system, there are two separate and distinct jurisdictions which correspond to the federalist levels: the state and the federal jurisdiction. According to the Constitution Society ${ }^{24}$ :

Broadly speaking, state jurisdiction encompasses the legislative power to regulate, control and govern real and personal property, individuals and enterprises within the territorial boundaries of any given State. In contrast, federal jurisdiction is extremely limited, with the same being exercised only in areas external to state legislative power and territory.

And it is the federal jurisdiction that has a constitutional provision, in Article 3, section $2^{25}$. So federal courts have a tailored jurisdiction and will decide how to interpret the Constitution, laws passed by Congress and treaties. The federal courts will also decide disputes that may arise between states, between citizens of different states, and between states. All the cases that are related to the federal government also fell under federal jurisdiction. The federal courts also decide on federal crimes.

In Brazil there are two separate and distinct jurisdictions too: the federal and state jurisdiction, but a major and relevant distinction has to be made now.

In short in US if a case deals with federal law, a federal judge will settle the dispute. But that is not true in Brazil because another standard of jurisdiction division was adopted. According to articles 108 and 109, federal judges and courts have jurisdiction in many cases, but only and if the federal government or one of its agencies or a federal public company have an interest in the case. The exception cases are bankruptcy, job-related accidents and those subject to the Electoral and Labour Courts. There is also federal jurisdiction for federal

\footnotetext{
${ }^{24}$ Available at :<http://www.constitution.org/juris/fedjur1.htm>.

${ }^{25}$ This is the constitutional language: "The judicial Power shall extend to all Cases, in Law and Equity, arising under this Constitution, the Laws of the United States, and Treaties made, or which shall be made, under their Authority;--to all Cases affecting Ambassadors, other public Ministers and Consuls;--to all Cases of admiralty and maritime Jurisdiction;--to Controversies to which the United States shall be a Party;-- to Controversies between two or more States;--between a State and Citizens of another State;--between Citizens of different States;--between Citizens of the same State claiming Lands under Grants of different States, and between a State, or the Citizens thereof, and foreign States, Citizens or Subjects."
} 
crimes. So the state jurisdiction is considered a residual one because if the case is not supposed to be heard by a federal judge ${ }^{26}$, it will be heard by a state court.

So the legislative origin of the statue (which is crucial in determining the American federal jurisdiction) is irrelevant to fix the federal Brazilian jurisdiction. And the Federal Judicial Branch exists mainly in order to manage the conflicts related to the Union, aka the federal government. We have to consider here that most of Brazilian law is originated by the Federal Congress so if the division of jurisdiction were to be the same that US adopts, state judges in Brazil would rarely hear a case. So it doesn't matter if the law is federal, if the Union is not a plaintiff or a defendant, the case will go to a state judge. As a consequence of this system there is a huge range of different interpretations regarding the same statute all over the country, and moreover federal judges as well as state judges may be called to decide a case under the same national Code.

As a Brazilian legal paradox, we have a broad national wide normative system whichmight suggest an appreciation for uniformity, but at the same time there is no real guarantee that the meaning of the law will be the same, especially when the Higher Courts cannot convey a shared meaning that would lead to more solid understandings of the law. Quite the opposite! which gets really serious in a legal culture, as the Brazilian one, that stresses judicial independence over consensus, celebrates legal controversies and resists fiercely against binding decisions. The text is the same, but the law that should function as a reference for social behaviour is not. This might pose some issues when we consider the role of equal treatment in protecting rights within the boundaries of predictability.

\section{References $^{27}$}

BAHIA, Bruno Gomes. Do princípio federativo. Conteudo Juridico, Brasilia-DF: 22 jan. 2013. Disponivel em: <http://www.conteudojuridico.com.br/?artigos\&ver=2.41826\&seo=1>. Acesso em: 17 jun. 2017.

BULMAN-POZEN, Jessica. Executive Federalism Comes to America. Disponível em:<http://www.virginialawreview.org/sites/virginialawreview.org/files/BulmanPozen_Online.pdf $>$. Acesso em: 10 jan 2018.

\footnotetext{
${ }^{26}$ In Brazil's legal system, there are also federal courts (such as labour, electoral and military courts) with specialized jurisdiction that are organized as a special branch. To learn more, see articles 111; 118 and 122. ${ }^{27}$ These references follow ABNT's rules as it is the technical pattern in Brazilian academic papers.
} 
BRASIL. Constituição da República Federativa do Brasil de 1988. Disponível em: <http://www.planalto.gov.br/ccivil_03/constituicao/constituicao.htm>. Acesso em: 15 jun 2017.

CAMARGOS, Luciano Dias Bicalho. ANJOS, Marcelo Adriano Menacho dos. Tipos de Estado. In: FERREIRA, Lier Pires. GUANABARA, Ricardo. JORGE, Vladimyr Lombardo (org.). Curso de Teoria Geral do Estado. Rio de Janeiro: Elsevier, 2009, pp. 75-100.

CARVALHO, José Murilo de. Os bestializados. São Paulo: Companhia das Letras, 1991.

CHACON, Vamireh. Vida e Morte das Constituições Brasileiras. Rio de Janeiro: Forense, 1987.

CORLEY, Pamela. C; WARD, Artemus; MARTINEK, Wendy L. American judicial process. Mith and reality in Law and Courts. New York: Routledge, 2016.

Death Penalty Information Center. Disponível em: <https://deathpenaltyinfo.org/descriptionsexecution-methods?scid=8\&amp;did=479>. Acesso em 17 jun 2017.

ERBSEN, Allan, Horizontal Federalism (September 4, 2008). Minnesota Law Review, Vol. 93, No. 2, 2008; Minnesota Legal Studies Research Paper No. 08-31; Georgetown Public Law Research Paper No. 1263682. Availableat SSRN: https://ssrn.com/abstract=1263682

GEERTZ, Clifford. A interpretação das culturas. Rio de Janeiro: LTC, 2008. . O saber local. Petrópolis: Vozes, 1998.

_. The interpretation of cultures. New York: Basic Books, 1973. Local knowlegde. New York: Basic Books, 1983.

GLUCK, Abbe. Our [National] Federalism. Disponível em: <https://www.yalelawjournal.org/pdf/1996.Gluck.2043_gweqfm59.pdf) >. Acesso em: 10 jan 2018.

GREVE, Michael. Our Polarized, Presidential Federalism. Disponível em: <https://papers.ssrn.com/sol3/papers.cfm?abstract_id=2885932> .Acesso em: 10 jan 2018.

HAMILTON, Alexander; MADISON, James; JAY, John.O Federalista. Campinas: Russell, 2003.

HEATHER, K. Gerken. Our Federalism(s). William \& Mary Law Review. Volume 53. Issue 5. Article 3, 2012.

IORIO FILHO, Rafael Mario. Uma questão da cidadania: o papel do Supremo Tribunal Federal na intervenção federal (1988-2008). Curitiba: CRV, 2014. 
IORIO FILHO, Rafael; DUARTE, Fernanda. A gramática das decisões judiciais: entre a igualdade e a desigualdade jurídica. In: Encontro da Associação Brasileira de Ciência Política, 7, Recife/PE, 2010. Anais... Rio de Janeiro: Associação Brasileira de Ciência Política, 2010.

LIJPHART, Arend. Modelos de democracia - Desempenho e padrões de governo em 36 países. Rio de Janeiro: Civilização Brasileira, 2003.

METZGER, Gillian. Administrative Law as the New Federalism. Disponível em: <http://scholarship.law.duke.edu/dlj/vol57/iss7/2/>. Acesso em: 10 jan 2018.

RICKER, W. Federalism. In: RICKER,W.Federalism.,in:BLUME,Lorenz, VOIGT, Stefan. Federalism and Decentralization - A Critical Survey of Frequently Used Indicators. ConstitutionalPoliticalEconomy. Volume 22, Issue 3, 2008, p.12.

SERAFIN, Gabriela Pietsch. O princípio federativo e a autonomia dos entes federados. Revista de Doutrina da $4^{a}$ Região, Porto Alegre, n. 58, fev. 2014. Disponível em: <http://www.revistadoutrina.trf4.jus.br/artigos/edicao058/Gabriela_Serafin.html> Acesso em: 17 jun. 2017.

SILVA, José Afonso da. Curso de Direito Constitucional Positivo. 27 ed. São Paulo: Malheiros, 2006.

TOCQUEVILLE, Alexis. A democracia na América. Leis e costumes. São Paulo: Martins Fontes, 2005. 